УДК 502/504.631.421

\title{
АМАРАНТ - ПЕРСПЕКТИВНОЕ РАСТЕНИЕ В ОХРАНЕ ОКРУЖАЮЩЕЙ СРЕДЫ
}

\author{
Шонтуков Тагир Заурович \\ аспирант \\ Бекалдиева Нарсана Муратовна \\ магистрант \\ Бейтуганов Исмаил Расулович \\ Забаков Азамат Борисович \\ Альборов Антемир Арсенович \\ студенты \\ Научный руководитель: Ханиева Ирина Мироновна \\ доктор с.х. наук, профессор \\ ФГБОУ ВО Кабардино-Балкарский ГАУ
}

Аннотация: В статье приводятся данные результатов исследований амаранта в качестве культуры, используемой как сорбент. Проведенные исследования показывают, что эта культура может быть использована в севообороте, накапливая органические вещества и сохраняя экологически чистую среду для последующих культур.

Ключевые слова: Амарант, сорбент, тяжелые металлы, биологически активные вещества.

Ограниченный набор культур в сельскохозяйственном производстве приводит к вспышке различных болезней растений, которые наносят огромный ущерб как в материальных затратах, так и в загрязнении окружающей среды. Поэтому введение в ротацию сельскохозяйственных культур новых и нетрадиционных растений способствует устойчивости и стабильности в растениеводстве.

Нерациональное применение химических средств и удобрений вызывает загрязненность почв тяжелыми металлами и радионуклидами, которые накапливаются в растительной пище. Применение и использование растений, связывающих вредные для человека химические элементы, является глобальной задачей охраны биосферы. 
В последние годы считают перспективной культурой амарант, ее используют как в пищевых, так и кормовых целях. Уникальность ее заключается в том, что она во всех частях растений содержит большое количество биологически активных веществ: заменимых и незаменимых аминокислот, микроэлементов, минералов, витаминов, протеинов, полиненасыщенных жирных кислот, холина, желчных кислот, спиринов, стероидов и сквалена. Для использования на кормовые цели пригодна как зеленая масса, так и семена. В семенах амаранта содержится 15-17\% белка, 5$8 \%$ жиров, 3,7-5,7\% клетчатки, - что выше, чем у большинства зерновых культур. Содержание липидов в зерне амаранта составляет 7,7\%, что в 1,5 раза выше, чем в зерне хлебных злаков (в среднем 1,1-6,7\%). Лизина в семенах амаранта содержится 4,3-5,7\% или в 2 раза больше, чем в зерне пшеницы и в 3 раза больше, чем в семенах кукурузы, сорго и других просяных культурах и даже сопоставимо по содержанию с соей. В белках амаранта отмечается повышенное содержание аминокислот, которые участвуют в механизме оптимального пищевого усвоения белков, основой которых является лейцин.

Амарант имеет высокие аллелопатические свойства и угнетает растения высеваемые совместно. Содержащие в амаранте флавоноиды, алкалоиды и ряд кислот, выделяемые этими растениями, являются отрицательными веществами для культуры, высеваемой в смеси, особенно бобового компонента, ингибируя процесс азотофиксации.

Оценка амаранта в предгорной зоне КБР показала, что урожай зеленой массы может достигать 50,0-70,0 т/га, что обеспечивает с каждого гектара более 10,0 т кормовых единиц и около 1,5 тонны переваримого протеина. Особенно ценным свойством амаранта является высокое содержание кремния во всех органах, в том числе и в корневой системе (2,5-3,0 \%).

Имея сорбционные свойства, кремний способен нейтрализовать тяжелые металлы в почвенном растворе. С целью изучения сорбционных возможностей сельскохозяйственных культур определяли в 0-20 см. слое почвы (выщелоченный чернозем, среднесуглинистый, $\mathrm{pH}-5,9$ ) ,содержание тяжелых металлов (медь, цинк, марганец).

Почвенные анализы осуществляли в звене севооборота. В качестве объекта исследований служили посевы клевера, люцерны, картофеля, кукурузы, сои и амаранта. В системе севооборота под картофель и кукурузу применяли удобрения, под сою перед посевом гербициды и без применения 
химических веществ возделывали люцерну, клевер и амарант. Все культуры шли по пласту озимой пшеницы.

Результаты химических анализов показали, что под амарантом сохранялось минимальное количество цинка (2,37 мг/кг сухой почвы ПДК 23,0 мг/кг). У клевера и люцерны количество цинка было несколько выше (2,5-2,9 мг/кг). С применением химических веществ уровень цинка под кукурузой и картофелем достигал 3-4 мг/кг, т.е. в допустимых пределах. Содержание марганца под амарантом колебалось в пределах 12-18 мг/кг (ПДК- 20 мг/кг). Максимальные количества (на 7-16 мг/кг выше ПДК) отмечены под соей и кукурузой. Наиболее значимые показатели по содержанию меди. С использованием удобрений повышается содержание меди до 4 мг/кг, что выше ПДК на 1 мг/кг. Под амарантом количество меди не превышало 2 мг/кг. В пределах 1,2-1,9 мг/кг отмечено меди в посевах бобовых трав.

Следовательно, амарант как сорбент может быть использован в севообороте, накапливая органические вещества и сохраняя экологически чистую среду для последующей культуры.

\section{Список литературы}

1. Биологический контроль окружающей среды. Генетический мониторинг. М.: Издательский центр «Академия».- 2010.- 136с.

2. Биологический контроль окружающей среды. Биоиндикация и биотестирование (под. ред. О.П. Мелеховой, Е.И. Сорапульцевой). - М.: Издательский центр «Академия».- 2010.- 156c.

3. Вельц Н.Ю. Изобретение «Способ оценки загрязнения окружающей среды тяжелыми металлами» Патент №2257597 от 27.07.2005г, МПК: G01V9/00, G01 №33/48.

4. Жеруков Б.Х., Способ детоксикации почв/ Жеруков Б.Х., Бекузарова C.А., Фарниев А.Т., Ханиева И.М., и др.// Патент на изобретение RU 2455812 C2, 20.07.2012. Заявка № 2009147560/13 от 21.12.2009.

5. Заалишвили В.Б., Осикина Р.В. Изобретение «Способ оценки экологического состояния территории» Патент №2375869 от 20.12.2009, МПК: AO1G 23/00. 
6. Ханиева И.М., Бекузарова С.А., Ханиев М.Х.,и др. «Способ снижения радиоактивности почв». патент № 258027, опубликован 20.06.2016.МПК В09С1/00.

7. Ханиева И.М., Биоиндикаторы и охрана окружающей среды/ Ханиева И.М. Бекузарова С.А.//В книге: Инновационная парадигма развития естественных наук. Монография. Петрозаводск, 2020. С. 38-49.

8. Цугкиев Б.Г., Басаев Т.Б., Гагиева Л.Ч. Экологические способы нейтрализации тяжелых металлов в почве. Земледелие, 2004, - №1, - с.15. 